\title{
PENINGKATAN PRODUKTIVITAS KERJA DENGAN PENDEKATAN KKNI MENGGUNAKAN METODE FULL TIME EQUIVALENT (Studi Kasus di PT. Rosy Ceramindo)
}

\section{INRCREASING WORK PRODUCTIVITY WITH KKNI APPROACH USING FULL TIME EQUIVALENT METHOD (Case Study at PT. Rosy Ceramindo)}

\author{
Hartono $^{1}$, Bobby Kevinda $\mathbf{M}^{2}$ \\ 1,2. Program Studi Teknik Industri, Fakultas Teknik, Universitas Muhammadiyah Tangerang \\ hartono@umt.ac.id, ㄹbobbykevinda@gmail.com
}

\begin{abstract}
Human Resources (HR) has an important role in a company. PT. Rosy Ceramindo is one of the companies engaged in manufacturing tableware. So we need to optimize the number of employees in accordance with their workload through workload analysis. Mapping employee competencies is made based on the job description of each position then compared to the Indonesian National Qualification Framework (KKNI). The method used is the Full Time Equivalent method using Java. The optimal number of employees based on FTE calculations for the Production Department is 94 people. Mapping of competencies based on job description and KKNI for the position of Section Chief is at level 6 equivalent to S1 or D4. For the positions of Mold Operators, Body Raw Material Milling Operators, Glaze Raw Material Milling Operators, Painting Operators, Pressure Casting Operators, Casting Operators, Finishing Operators, Decal Operators, Glazing Operators, and Roll Kiln Operators and Packing Operators at the levels. 2 is equivalent to SMA / SMK /MA.
\end{abstract}

Keywords : FTE, SDM, JAVA, KKNI, Productivity.

\begin{abstract}
ABSTRAK
Sumber Daya Manusia (SDM) memiliki peran penting dalam sebuah perusahaan. PT. Rosy Ceramindo merupakan salah satu perusahaan yang bergerak di bidang pembuatan tableware. Sehingga perlu pengoptimalan jumlah karyawan sesuai dengan beban kerjanya melalui analisis beban kerja. Pemetaan kompetensi karyawan dibuat berdasarkan job description tiap jabatan kemudian dibandingkan dengan Kerangka Kualifikasi Nasional Indonesia (KKNI). Metode yang digunakan adalah metode Full Time Equivalent dengan menggunakan Java. Jumlah karyawan optimal berdasarkan perhitungan FTE untuk Departemen Produksi adalah sebanyak 94 orang. Pemetaan kompetensi berdasarkan job description dan KKNI jabatan Kepala Bagian berada pada jenjang 6 setara dengan S1 atau D4. Untuk jabatan Operator Mould, Operator Milling Bahan Baku Body, Operator Milling Bahan Baku Glaze, Operator Painting, Operator Pressure Casting, Operator Casting, Operator Finishing, Operator Decal, Operator Pencelupan warna (glazing), dan Operator Roll Kiln dan Operator Packing berada pada jenjang 2 setara dengan SMA/SMK/MA.

Kata kunci : FTE, SDM, JAVA, KKNI, Produktivitas.
\end{abstract}

\section{PENDAHULUAN}

\subsection{Latar Belakang}

Sumber Daya Manusia PT. Rosy Ceramindo merupakan asset yang sangat berharga bagi keberlangsungan perusahaan. Karena Sumber Daya Manusia dapat membuat perusahaan tersebut tetap maju dan berkembang. Semua Sumber Daya Manusia di PT. Rosy Ceramindo ikut ambil alih dalam keberlangsungan perusahaan, tidak hanya management representative saja tetapi divisi marketing, engineering, logistik, produksi, personalia, dan finance. Saat ini jumlah karyawan yang terdapat pada pada divisi produksi adalah sejumlah 86 orang karyawan tetap. 
Tabel 1.1 Data Hasil Capaian Produksi PT.Rosy Ceramindo

\begin{tabular}{|c|c|c|c|}
\hline Bulan & $\begin{array}{c}\text { Jumlah } \\
\text { Produksi }\end{array}$ & $\begin{array}{c}\text { Target } \\
\text { Produksi }\end{array}$ & $\begin{array}{c}\text { Persentase Capaian } \\
\text { Hasil Produksi }\end{array}$ \\
\hline Jan-19 & 145455 & 149245 & $97.46 \%$ \\
\hline Feb-19 & 129122 & 133120 & $97.00 \%$ \\
\hline Mar-19 & 135245 & 138500 & $97.65 \%$ \\
\hline Apr-19 & 142865 & 150200 & $95.12 \%$ \\
\hline May-19 & 154780 & 159200 & $97.22 \%$ \\
\hline Jun-19 & 187068 & 192500 & $97.18 \%$ \\
\hline Jumlah & 894535 & 922765 & $96.94 \%$ \\
\hline
\end{tabular}

Dari tabel diatas menunjukan bahwa rata-rata persentase hasil capaian produksi PT. Rosy Ceramindo bulan Januari-Juni 2019 sebesar 96,94\% dari jumlah produksi sebesar 894535 dan target produksi sebesar 922765. Selama ini, bagian perencanaan SDM belum pernah melakukan perhitungan beban kerja karyawan untuk mengoptimalkan jumlah karyawan. Pada saat ini hasil produksi PT. Rosy Ceramindo selama 6 bulan mengalami penurunan yang cukup signifikan dikarenakan tidak mencapai target yang diinginkan perusahaan akibatnya produktivitas perusahaan rendah. Tujuan daripenelitian ini adalah menghitung jumlah kebutuhan karyawan optimal menggunakan Java berdasarkan metode FTE, menentukan pemetaan kuallifikasi karyawan yang sesuai berdasarkan KKNI, mengetahui hasil target produksi setelah di terapkan pengoptimalan karyawan dengan menggunakan metode FTE dan pemetaan karyawan sesuai KKNI.

\subsection{Tinjauan Pustaka}

\section{Produktivitas}

Pengertian Produktivitas menurut Handoko (2011), Produktivitas adalah hubungan antara masukan-masukan dan keluaran-keluaran suatu sistem produktif. Dalam teori, sering mudah untuk mengukur hubungan ini sebagai rasio keluaran dibagi masukan. Bila lebih banyak keluaran diproduksi dengan jumlah masukan sama, produktivitas naik. Begitu juga, bila lebih sedikit masukan digunakan untuk sejumlah keluaran sama, produktivitas juga naik. Adapun rumus untuk menghitung produktivitas adalah sebagai berikut :

Produktivitas $=\frac{\text { Hasil Total }}{\text { Masukan Total }}$

\section{Analisis Beban Kerja}

Menurur Suwatno (2003) dalam Muryani (2016), Beban kerja adalah sejumlah kegiatan yang harus diselesaikan oleh suatu unit organisasi atau pemegang jabatan secara sistematis dengan menggunakan teknik analisis jabatan, teknik analisa beban kerja, atau teknik manajemen lainnya dalam jangka waktu tertentu untuk mendapatkan informasi tentang efisiensi dan efektifitas kerja suatu unit organisasi. Beban kerja seseorang sudah ditentukan dalam bentuk standar kerja perusahaan menurut jenis pekerjaannya. Apabila sebagian besar karyawan bekerja sesuai dengan standar perusahaan, maka tidak menjadi masalah. Sebaliknya, jika karyawan bekerja di bawah standar maka beban kerja yang diemban berlebih. Sementara jika karyawan bekerja di atas standar, dapat berarti estimasi standar yang ditetapkan lebih rendah dibanding kapasitas karyawan itu sendiri. Kebutuhan SDM dapat dihitung dengan mengidentifikasikan seberapa banyak output perusahaan pada divisi tertentu yang ingin dicapai. Unit pelaksana mengolah data laporan beban kerja dari satuan unit/satuan organisasi dengan menghitung isi kerjanya,dengan rumus :

Isi Kerja $=$ Beban Kerja $\mathrm{x}$ Norma Waktu. 


\section{Full Time Equivalent}

Dewi dan Satrya (2012) mengungkapkan implikasi dari nilai FTE terbagi menjadi 3 jenis yaitu overload, normal, dan underload. Berdasarkan pedoman analisis beban kerja yang dikeluarkan oleh Badan Kepegawaian Negara pada tahun 2010, total nilai indeks FTE yang berada di atas nilai 1,28 dianggap overload, berada diantara nilai 1 sampai dengan 1,28 dianggap normal sedangkan jika nilai indeks FTE berada diantara nilai 0 sampai dengan 0,99 dianggap underload atau beban kerjanya masih kurang. Untuk mendapatkan nilai FTE dari suatu proses kerja adalah sebagai berikut :

FTE $=\frac{\text { Total Working hours/year+allowance }}{\text { effective working hours/year }}$.

\section{KNNI (Kerangka Kualifikasi Nasional Indonesia)}

Kerangka Kualifikasi Nasional Indonesia (KKNI) adalah kerangka penjenjangan kualifikasi sumber daya manusia Indonesia yang menyandingkan, menyetarakan, dan mengintegrasikan sektor pendidikan dengan sektor pelatihan dan pengalaman kerja dalam suatu skema pengakuan kemampuan kerja yang disesuaikan dengan struktur di berbagai sektor pekerjaan (Tim KKNI, 2018). KKNI merupakan perwujudan mutu dan jati diri bangsa Indonesia terkait dengan sistem pendidikan nasional, sistem pelatihan kerja nasional, dan sistem penilaian kesetaraan capaian pembelajaran (learning outcomes) nasional, yang dimiliki Indonesia untuk menghasilkan sumber daya manusia nasional yang bermutu dan produktif (Tim KKNI, 2018).

KKNI diatur oleh Peraturan Presiden Nomor 8 Tahun 2012, yang merupakan penjabaran dari peraturan-peraturan yang lebih tinggi.Dalam peraturan tersebut, pada Pasal 1 ayat (1), dijelaskan bahwa yang dimaksud dengan Kerangka Kualifikasi Nasional Indonesia (KKNI) adalah kerangka penjenjangan kualifikasi kompetensi yang dapat menyandingkan, menyetarakan, dan mengintegrasikan antara bidang pendidikan dan bidang pelatihan kerja serta pengalaman kerja dalam rangka pemberian pengakuan kompetensi kerja sesuai dengan struktur pekerjaan di berbagai sektor (Tim KKNI, 2018).

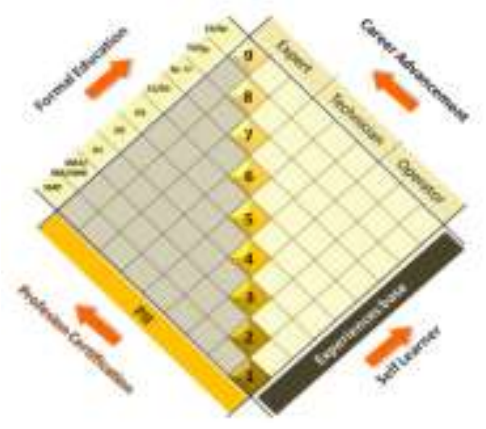

Gambar 1.1. Gambaran Kerangka Kualifikasi Nasional Indonesia

Sumber: http://kkni-kemenristekdikti.org/paradigma, 2018

\section{METODOLOGI}

Penelitian ini menggunakan metode penelitian analitik observasional dengan pendekatan cross sectional. Analitik observasional dengan pendekatan cross sectional adalah penelitian yang dilakukan pada saat satu atau satu periode tertentu dan pengamatan objek studi hanya dilakukan satu kali. Pada jenis ini, variabel dinilai secara simultan pada suatu saat, sehingga tidak ada tindak lanjut. Penelitian ini juga menggunakan metode penelitian kuantitatif karena terstruktur secara sistematis sejak awal hingga pembuatan desain penelitiannya. Pendekatan kuantitatif adalah penelitian yang banyak menuntut pengguanaan angka, mulai dari pengumpulan data, penafsiran data tersebut, serta penampilan dari hasilnya

Dalam penelitian ini penggunaan metode yang dimaksud terdapat pada tahapan analisis beban kerja dengan melakukan perhitungan beban kerja menggunakan Full Time Equivalent (FTE) dengan hasil dari analisis beban kerja tersebut adalah jumlah karyawan 
yang optimal. Selanjutnya peneliti membuat program aplikasi yang dapat membantu bagian perencanaan SDM untuk menghitung beban kerja dari setiap jabatan dengan menggunakan Java. Lalu, peneliti melakukan pemetaan kompetensi karyawan berdasarkan job description dari setiap jabatan yang kemudian dibandingkan dengan Kerangka Kualifikasi Nasional Indonesia (KKNI). Hasil dari pemetaan ini adalah rekomendasi persyaratan jabatan yang dilihat dari pendidikan terakhir untuk menempuh suatu jabatan tertentu.

a. Flowchart Pengolahan Data Beban Kerja

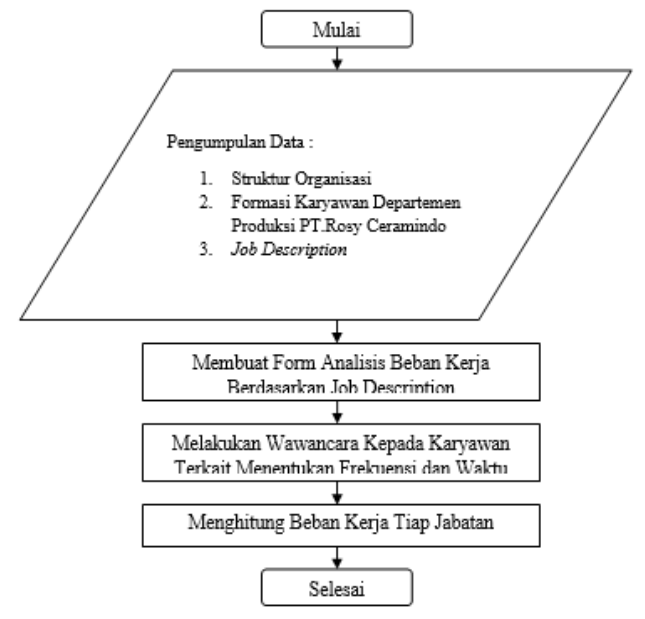

Gambar 2.1. Flowchart Pengolahan Data Beban Kerja

b. Flowchart Pengolahan Data Perhitungan Kebutuhan Karyawan Optimal

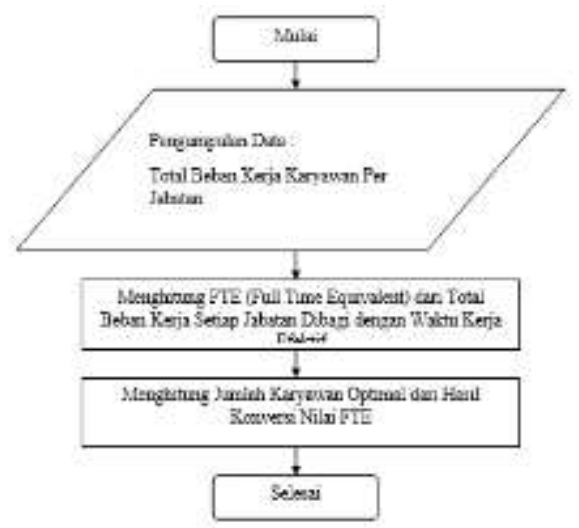

Gambar 2.2. Flowchart Pengolahan Data Perhitungan Kebutuhan Karyawan Optimal 
c. Flowchart Pengolahan Data Pembuatan Program Aplikasi Beban

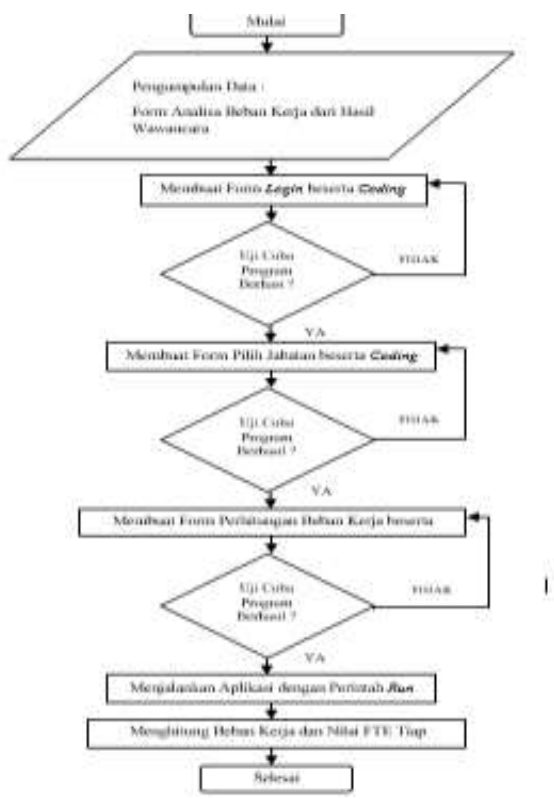

Gambar 2.3. Flowchart Pengolahan Data Pembuatan Program Aplikasi Beban

d. Flowchart Pengolahan Data Pemetaan Kompetensi Karyawan

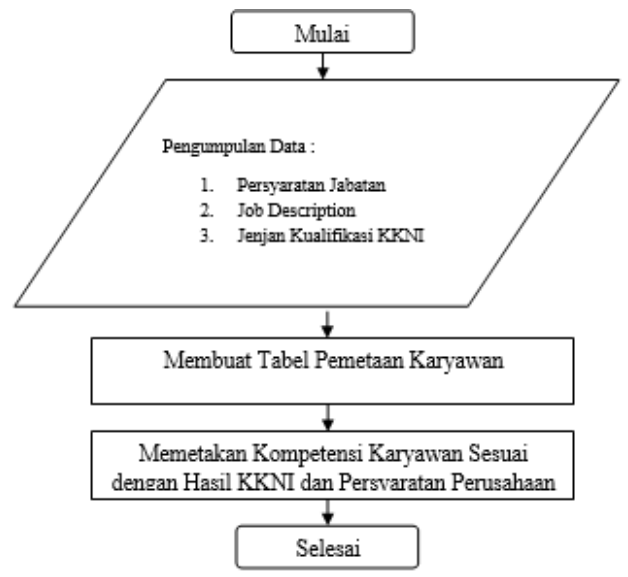

Gambar 2.4. Flochart Pengolahan Data Pemetaan Kompetensi Karyawan

\section{HASIL DAN PEMBAHASAN}

\subsection{Pengumpulan Data}

Tabel 3.1 Data Produksi PT. Rosy Ceramindo Bulan Januari - Juni 2019

\begin{tabular}{|c|c|c|c|}
\hline Bulan & $\begin{array}{c}\text { Jumlah } \\
\text { Produksi }\end{array}$ & $\begin{array}{c}\text { Target } \\
\text { Produksi }\end{array}$ & $\begin{array}{c}\text { Persentase Capaian } \\
\text { Hasil Produksi }\end{array}$ \\
\hline Jan-19 & 145455 & 149245 & $97.46 \%$ \\
\hline Feb-19 & 129122 & 133120 & $97.00 \%$ \\
\hline Mar-19 & 135245 & 138500 & $97.65 \%$ \\
\hline Apr-19 & 142865 & 150200 & $95.12 \%$ \\
\hline May-19 & 154780 & 159200 & $97.22 \%$ \\
\hline Jun-19 & 187068 & 192500 & $97.18 \%$ \\
\hline Jumlah & 894535 & 922765 & $96.94 \%$ \\
\hline
\end{tabular}

Pada tabel diatas dapat dilihat bahwa pada bulan Januari jumlah produksi sebesar 145455, target produksi sebesar 149245 dan Persentase Pencapaian hasil produksi $97.46 \%$. Pada bulan Februari jumlah produksi sebesar 129122, target produksi sebesar 133120 dan 
Pencapaian hasil produksi $97.00 \%$. Pada bulan Maret jumlah produksi sebesar 135245, target produksi sebesar 138500 dan Pencapaian hasil produksi 97.65\%. Pada bulan April jumlah produksi sebesar 142865, target produksi sebesar 150200 dan angka Pencapaian hasil produksi yaitu $95.12 \%$. Angka Pencapaian hasil produksi pada bulan april menunjukan bahwa target tidak tercapai 2 kali lipat dari bulan sebelumnya. Disusul pada bulan Mei jumlah produksi sebesar 154780, target produksi sebesar 159200 dan Pencapaian hasil produksi yaitu $97.22 \%$ dan pada bulan Juni jumlah produksi sebesar 187068, target produksi sebesar 192500 dan Pencapaian hasil produksi yaitu $97.18 \%$.

Tabel 3.2 Formasi Karyawan Departemen Produksi

\begin{tabular}{|c|l|c|c|}
\hline No & \multicolumn{1}{|c|}{ Jabatan } & $\begin{array}{c}\text { Jumlah } \\
\text { Karyawan }\end{array}$ & $\begin{array}{c}\text { Jumlah } \\
\text { Mesin }\end{array}$ \\
\hline 1 & Kepala Bagian & 6 & \\
\hline 2 & Operator Mould & 4 & 1 \\
\hline 3 & Operator Milling Bahan Baku Body & 2 & 1 \\
\hline 4 & Operator Milling Bahan Baku Glaze & 2 & 1 \\
\hline 5 & Operator Painting & 3 & \\
\hline 6 & Operator Pressure Casting & 4 & 4 \\
\hline 7 & Operator Casting & 12 & \\
\hline 8 & Operator Finishing & 23 & \\
\hline 9 & Operator Decal & 8 & \\
\hline 10 & Operator Pencelupan warna (Glazing) & 9 & \\
\hline 11 & Operator Roll Kiln & 4 & 1 \\
\hline 12 & Operator Packing & 9 & \\
\hline & $\quad$ Jumlah & 86 & 8 \\
\hline
\end{tabular}

Sumber: Data Perusahaan, 2019

Berdasarkan tabel di atas, dapat dilihat formasi karyawan yang ada di Departemen Produksi pada PT. Rosy Ceramindo. Jumlah karyawan yang ada pada Departemen Produksi sejumlah 86 orang.

Tabel 3.3 Persyaratan Jabatan Karyawan

\begin{tabular}{|c|c|c|c|c|c|c|c|c|c|}
\hline \multirow{2}{*}{ NO. Jabatan } & & \multicolumn{7}{|c|}{ Pendidikan } \\
\hline & & SD & SMP & SMA & D1 & D2 & D3 & D4 & S1 \\
\hline 1 & Kepala Bagian & & & & & & & & \\
\hline 2 & Operator Mould & & & & & & & & \\
\hline 3 & $\begin{array}{c}\text { Operator Milling Bahan } \\
\text { baku Body }\end{array}$ & & & & & & & & \\
\hline 4 & $\begin{array}{c}\text { Operator Milling Bahan } \\
\text { Baku Glaze }\end{array}$ & & & & & & & & \\
\hline 5 & Operator Painting & & & & & & & & \\
\hline 6 & Operator Pressure Casting & & & & & & & & \\
\hline 7 & Operator Casting & & & & & & & & \\
\hline 8 & Operator Finishing & & & & & & & & \\
\hline 9 & Operator Decal & & & & & & & & \\
\hline 10 & $\begin{array}{c}\text { Operator Pencelupan } \\
\text { warna Glazing }\end{array}$ & & & & & & & & \\
\hline 11 & Operator Roll Kiln & & & & & & & & \\
\hline 12 & Operator Packing & & & & & & & & \\
\hline
\end{tabular}

Sumber: Data Perusahaan 2019

\subsection{Pengolahan Data}

Berikut ini merupakan pengolahan data yang dilakukan dalam penelitian tentang perhitungan beban kerja karyawan pada PT. Rosy Ceramindo.

Contoh Perhitungan :

Total Beban Kerja

Kepala Bagian $=88980$

JIM, Vol. 6, No. 2, Agustus 2021, pp.73 - 86 
Total Keseluruhan

Beban Kerja $=$ Total Beban Kerja $\times$ Jumlah Karyawan $=88980 \times 6=533880$ (menit)

FTE Total $=\frac{\text { Total keseluruhan beban kerja }}{\text { Waktu kerja efektif }}$

$$
\begin{aligned}
& =\frac{533880}{80360} \\
& =6.6436
\end{aligned}
$$

\begin{tabular}{|c|c|c|c|c|}
\hline No & Uraian Tugas & $\begin{array}{c}\text { Frekuensi } \\
\text { Tugas dalam } 1 \\
\text { Tahun }\end{array}$ & $\begin{array}{c}\text { Waktu } \\
\text { Penyelesaian } \\
\text { Tugas (menit) }\end{array}$ & $\begin{array}{c}\text { Jumlah Beban } \\
\text { Kerja (menit) }\end{array}$ \\
\hline 1 & $\begin{array}{l}\text { Melakukan pemeriksaan } \\
\text { terhadap segala sesuatu yang } \\
\text { berhubungan dengan produksi }\end{array}$ & 287 & 120 & 34440 \\
\hline 2 & $\begin{array}{l}\text { Mengatur dan mengarahkan } \\
\text { kegiatan proses produksi pada } \\
\text { PT. Rosy Ceramindo untuk } \\
\text { memastikan operasi mesin } \\
\text { berjalan lancar dan bekerja } \\
\text { sesuai standar SOP serta } \\
\text { mencapai target kualitas dan } \\
\text { kuantitas produksi yang } \\
\text { ditentukan }\end{array}$ & 48 & 60 & 2880 \\
\hline 3 & $\begin{array}{l}\text { Mengatur dan mengarahkan } \\
\text { penggunaan bahan baku } \\
\text { /mesin sesuai dengan orderan } \\
\text { yang diterima. }\end{array}$ & 287 & 60 & 17220 \\
\hline 4 & $\begin{array}{l}\text { Melakukan pengawasan } \\
\text { terhadap kinerja operator } \\
\text { produksi dan bertanggung } \\
\text { jawab atas pekerjaan yang } \\
\text { dilakukan oleh operator } \\
\text { produksi }\end{array}$ & 287 & 120 & 34440 \\
\hline \multicolumn{4}{|c|}{ Total Beban Kerja } & 88980 \\
\hline \multicolumn{4}{|c|}{ Total Keseluruhan Beban Kerja } & 533880 \\
\hline \multicolumn{4}{|c|}{ FTE Total } & 6.643603783 \\
\hline \multicolumn{4}{|c|}{ FTE Individu } & 1.107267297 \\
\hline
\end{tabular}

Tabel 3.4. Formulir Beban Kerja Kepala bagian Produksi 


\subsection{Analisa dan Pembahasan}

Tabel 3.5 Jumlah Beban Kerja Karyawan pada Departemen Produksi

\begin{tabular}{|c|l|c|}
\hline No & \multicolumn{1}{|c|}{ Nama Jabatan } & $\begin{array}{c}\text { Total Beban Kerja } \\
\text { Keseluruhan (Menit) }\end{array}$ \\
\hline 1 & Kepala Bagian & 533880 \\
\hline 2 & Operator Mould & 430500 \\
\hline 3 & Operator Milling Bahan baku Body & 111930 \\
\hline 4 & Operator Milling Bahan Baku Glaze & 80360 \\
\hline 5 & Operator Painting & 370230 \\
\hline 6 & Operator Pressure Casting & 533820 \\
\hline 7 & Operator Casting & 1322496 \\
\hline 8 & Operator Finishing & 1960497 \\
\hline 9 & Operator Decal & 964320 \\
\hline 10 & Operator Pencelupan warna Glazing & 746487 \\
\hline 11 & Operator Roll Kiln & 323736 \\
\hline 12 & Operator Packing & 545013 \\
\hline \multicolumn{2}{|c|}{ Jumlah Total Beban Kerja Keseluruhan } & 7923269 \\
\hline
\end{tabular}

Dari tabel 3.5 didapatkan jumlah beban kerja dari setiap jabatan. Maka dapat diketahui jumlah keseluruhan dari beban kerja di Departemen Produksi pada PT. Rosy Ceramindo adalah sebesar 7.923.269 menit.

Tabel 3.6 Jumlah FTE Total dan FTE Individu

\begin{tabular}{|c|l|c|c|c|c|}
\hline No & \multicolumn{1}{|c|}{ Nama Jabatan } & FTE Total & $\begin{array}{c}\text { Jumlah } \\
\text { Karyawan }\end{array}$ & $\begin{array}{c}\text { FTE } \\
\text { Individu }\end{array}$ & Ket. \\
\hline 1 & Kepala Bagian & 6.643603783 & 6 & 1.107267297 & Fit \\
\hline 2 & Operator Mould & 5.357142857 & 4 & 1.339285714 & Overload \\
\hline 3 & $\begin{array}{l}\text { Operator Milling } \\
\text { Bahan baku Body }\end{array}$ & 1.392857143 & 2 & 0.696428571 & Underload \\
\hline 4 & $\begin{array}{l}\text { Operator Milling } \\
\text { Bahan Baku Glaze }\end{array}$ & 1 & 2 & 0.5 & Underload \\
\hline 5 & Operator Painting & 4.607142857 & 3 & 1.535714286 & Overload \\
\hline 6 & $\begin{array}{l}\text { Operator Pressure } \\
\text { Casting }\end{array}$ & 6.642857143 & 4 & 1.660714286 & Overload \\
\hline 7 & Operator Casting & 16.45714286 & 12 & 1.371428571 & Overload \\
\hline 8 & Operator Finishing & 24.39642857 & 23 & 1.060714286 & Fit \\
\hline 9 & Operator Decal & 12 & 8 & 1.5 & Overload \\
\hline 10 & $\begin{array}{l}\text { Operator Pencelupan } \\
\text { warna Glazing }\end{array}$ & 9.289285714 & 9 & 1.032142857 & Fit \\
\hline 11 & Operator Roll Kiln & 4.028571429 & 4 & 1.007142857 & Fit \\
\hline 12 & Operator Packing & 6.782142857 & 9 & 0.753571429 & Underload \\
\hline
\end{tabular}


Contoh perhitungan untuk jabatan Operator Mould:

FTE Total Operator Mould $=\frac{\text { Beban Kerja Keseluruhan Operator Mould (menit) }}{\text { Waktu Kerja Efektif }(\text { menit } / \text { tahun })}=\frac{430500}{80360}=5.3571$

FTE Individu $\quad=\frac{\text { FTE Total }}{\text { Jumlah Karyawan }}=\frac{5.3571}{4}=1.3392($ Overload $)$

Tabel 3.7. Jumlah Kebutuhan Karyawan Minimal

\begin{tabular}{|c|l|c|}
\hline No. & \multicolumn{1}{|c|}{ Nama Jabatan } & $\begin{array}{c}\text { Jumlah Karyawan } \\
\text { Yang Dibutuhkan }\end{array}$ \\
\hline 1 & Kepala Bagian & 6 \\
\hline 2 & Operator Mould & 5 \\
\hline 3 & Operator Milling Bahan baku Body & 1 \\
\hline 4 & Operator Milling Bahan Baku Glaze & 2 \\
\hline 5 & Operator Painting & 4 \\
\hline 6 & Operator Pressure Casting & 6 \\
\hline 7 & Operator Casting & 16 \\
\hline 8 & Operator Finishing & 23 \\
\hline 9 & Operator Decal & 12 \\
\hline 10 & Operator Pencelupan warna Glazing & 9 \\
\hline 11 & Operator Roll Kiln & 4 \\
\hline 12 & Operator Packing & 6 \\
\hline Jumlah yang dibutuhkan & 94 \\
\hline
\end{tabular}

Berdasarkan tabel 3.7, didapatkan jumlah kebutuhan karyawan mnimal. Untuk jumlah karyawan minimal yaitu sebanyak 12 orang, dengan usulan penambahan karyawan sebanyak 8 orang dari jumlah karyawan sebelumnya.

Tabel 3.8 Pemetaan Karyawan berdasarkan KKNI

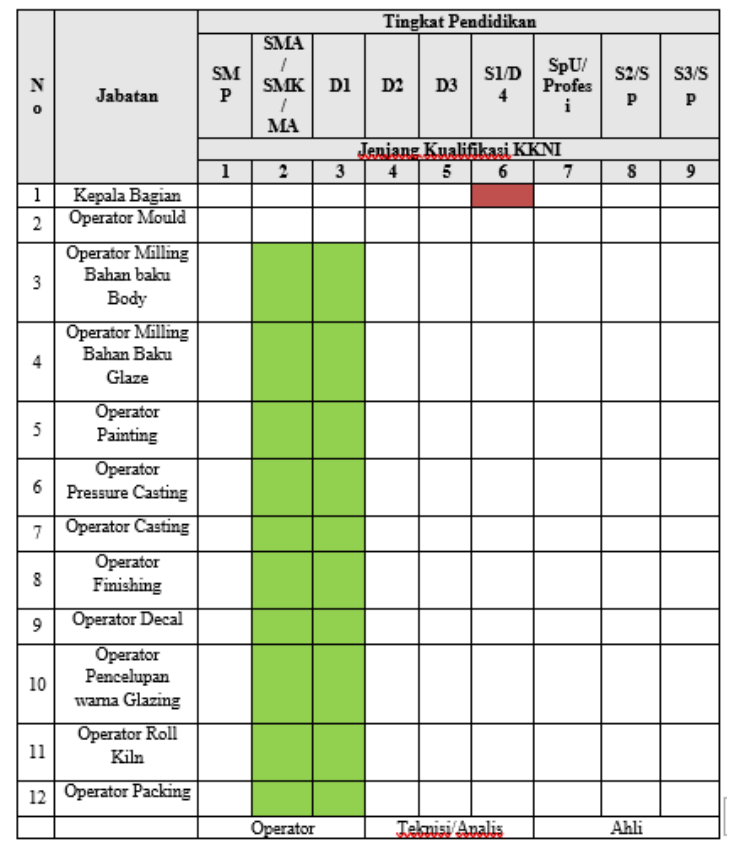

Berdasarkan tabel 3.8 , dapat diketahui pemetaan kompetensi karyawan Departemen Produksi PT. Rosy Ceramindo berdasarkan Kerangka Kualifikasi Nasional Indonesia (KKNI). Pemetaan karyawan dibuat dengan melihat job description kemudian dibandingkan dengan KKNI pada tabel 2.1 . Pada KKNI terdapat 9 jenjang pemetaan yang telah ditetapkan seperti pada Gambar 1.1. Hasil dari pemetaan ini adalah rekomendasi persyaratan jabatan yang dilihat dari pendidikan 
terakhir yang ditempuh untuk menempati suatu jabatan tertentu. Apabila terdapat perbedaan antara persyaratan jabatan yang telah ditetapkan perusahaan dengan hasil persyaratan berdasarkan KKNI, maka diharapkan dapat menjadi pertimbangan dalam menentukan karyawan baru.

Tabel 3.9 Pengoptimalan Karyawan

\begin{tabular}{|l|c|c|c|c|}
\hline \multicolumn{1}{|c|}{ Nama Jabatan } & $\begin{array}{c}\text { Jumlah } \\
\text { Karyawan } \\
\text { Saat Ini }\end{array}$ & $\begin{array}{c}\text { Jumlah } \\
\text { Karyawan } \\
\text { Sesudah } \\
\text { Dioptimalka } \\
\mathrm{n}\end{array}$ & $\begin{array}{c}\text { Jumlah } \\
\text { Karyawan } \\
\text { Yang } \\
\text { Dibutuhka } \\
\mathrm{n}\end{array}$ & Ket \\
\hline Kepala Bagian & 6 & 6 & 6 & - \\
\hline Operator Mould & 4 & 4 & 5 & $(-1)$ \\
\hline Operator Milling Bahan baku Body & 2 & 1 & 1 & - \\
\hline $\begin{array}{l}\text { Operator Milling Bahan Baku } \\
\text { Glaze }\end{array}$ & 2 & 2 & 2 & - \\
\hline Operator Painting & 3 & 3 & 4 & $(-1)$ \\
\hline Operator Pressure Casting & 4 & 4 & 6 & $(-2)$ \\
\hline Operator Casting & 12 & 14 & 16 & $(-2)$ \\
\hline Operator Finishing & 23 & 23 & 23 & - \\
\hline Operator Decal & 8 & 10 & 12 & $(-2)$ \\
\hline $\begin{array}{l}\text { Operator Pencelupan warna } \\
\text { Glazing }\end{array}$ & 9 & 9 & 9 & - \\
\hline Operator Roll Kiln & 4 & 4 & 4 & - \\
\hline Operator Packing & 9 & 6 & 6 & - \\
\hline \multicolumn{1}{|c|}{ Jumlah Karyawan } & 86 & 86 & 94 & $(-8)$ \\
\hline
\end{tabular}

Pada Tabel 3.9 dapat dilihat pembagian operator packing yang berlebih yaitu 3 orang dipindahkan pada bagian operator Decal 2 orang dan operator Casting 1 orang. operator milling bahan baku body yang berlebih yaitu 1 orang dipindahkan pada bagian Casting 1 orang. Sehingga usulan penambahan karyawan untuk PT.Rosy Ceramindo yaitu sebanyak 8 karyawan.

Berdasarkan dari hasil perhitungan beban kerja menggunakan metode Ful Time Equivalent (FTE) pada Tabel 3.6 maka dibutuhkan jumlah karyawan minimal 94 karyawan, sedangkan karyawan PT. Rosy Ceramindo saat ini yaitu 86. Maka dibutuhkan 8 karyawan untuk mengisi beberapa kegiatan operator agar mengurangi beban kerja. Berikut hasil capaian produksi 2 bulan pada bulan Juli dan Agustus.

Tabel 3.10 Hasil Capaian Produksi Bulan Juli-Agustus 2019

\begin{tabular}{|c|c|c|c|}
\hline Bulan & $\begin{array}{c}\text { Jumlah } \\
\text { Produksi }\end{array}$ & $\begin{array}{c}\text { Target } \\
\text { Produksi }\end{array}$ & $\begin{array}{c}\text { Persentase } \\
\text { Capaian Hasil } \\
\text { Produksi }\end{array}$ \\
\hline July-19 & 152422 & 155350 & $98.12 \%$ \\
\hline Aug-19 & 149320 & 152200 & $98.11 \%$ \\
\hline Jumlah & 301742 & 307550 & $98.11 \%$ \\
\hline
\end{tabular}

Pada tabel diatas dapat dilihat bahwa pada bulan juli jumlah produksi sebesar 152422, target produksi sebesar 155350 dan Persentase Pencapaian hasil produksi 98.12\%. Pada bulan Agustus jumlah produksi sebesar 149320, target produksi sebesar 152200 dan Pencapaian hasil produksi 98.11\%. Jumlah produksi bulan Juli-Agustus 2019 yaitu 301742 dan jumlah target produksi bulan Juli-Agustus 2019 yaitu 307550. Didapat capaian hasil produksi bulan Juli-Agustus yaitu 98.11\% jumlah ini mengalami kenaikan sebesar $1.17 \%$ dari persentase capaian hasil produksi pada bulan Januari-Juni 2019 yaitu 96.94\%. 
Tabel 3.11 Produktivitas Pengoptimalan karyawan PT. Rosy Ceramindo berdasarkan FTE

\begin{tabular}{|c|c|c|c|}
\hline \multicolumn{4}{|c|}{ Sebelum Dioptimalkan } \\
\hline Bulan & Jumlah Produksi & Jumlah Karyawan & Jumlah Pcs/Bulan \\
\hline Jan-19 & 145455 & 86 & 1691.34 \\
\hline Feb-19 & 129122 & 86 & 1501.42 \\
\hline Mar-19 & 135245 & 86 & 1572.62 \\
\hline Apr-19 & 142865 & 86 & 1661.22 \\
\hline May-19 & 154780 & 86 & 1799.77 \\
\hline Jun-19 & 187068 & 86 & 2175.21 \\
\hline \multicolumn{4}{|c|}{ Jumlah } \\
\hline \multicolumn{4}{|c|}{ Rata-rata } \\
\hline Sesudah Dioptimalkan \\
\hline Bulan & Jumlah Produksi & Jumlah Karyawan & Jumlah Pcs/bulan \\
\hline Jul-19 & 152422 & 86 & 1772.35 \\
\hline Aug-19 & 149320 & 86 & 1736.28 \\
\hline \multicolumn{4}{|c|}{ Jumlah } \\
\hline \multicolumn{4}{|c|}{ Rata-rata } \\
\hline
\end{tabular}

Pada tabel diatas dapat dilihatt bahwa bulan januari-Juni 2019 memiliki jumlah rata-rata yaitu 1733,59 pcs/orang dan setelah dioptimalkan berdasarkan nilai Full Time Equivalent pada bulan Juli dan Agustus 2019 jumlah rata rata meningkat sebesar 1754.31 maka dapat dihasilkan nilai produktivitas PT. Rosy Ceramindo sebagai berikut :

Total Produktivitas $=\frac{1754,31-1733,59}{1733,59}$

$$
\begin{aligned}
& =\frac{20,72}{1733,59} \\
& =0,0119 \\
& =1,20 \%
\end{aligned}
$$

Berdasarkan perhitungan diatas maka diketahui produktivitas PT. Rosy Ceramindo mengalami peningkatan sebesar 1,20\% pada bulan Juli dan Agustus 2019. Angka persentase sangat kecil dikarenakan PT. Rosy Ceramindo hanya mengoptimalkan 4 operator produksi yang sudah ada. Sementara itu permintaan jumlah karyawan berdasarkan nilai perhitungan FTE masih membutuhkan 8 orang karyawan untuk mengisi jabatan operator produksi di PT. Rosy Ceramindo.

\section{KESIMPULAN DAN SARAN}

\subsection{Kesimpulan} berikut:

Berdasarkan hasil dari penelitian yang telah dilakukan, maka didapatkan kesimpulan sebagai

a. Jumlah karyawan optimal Menggunakan Java berdasarkan perhitungan FTE untuk Departemen Produksi adalah sebanyak 94 orang dengan jumlah karyawan optimal yang berbeba-beda untuk setiap jabatannya. Untuk jabatan Operator Mould dan Operator Painting dibutuhkan 1 orang untuk setiap jabatan tersebut. Jabatan Operator Pressure Casting, Operator Casting dan Operator Decal dibutuhkan 2 orang untuk masing-masing jabatan. Operator yang dioptimalkan adalah operator Packing berjumlah 3 orang dan Operator Milling Bahan Baku Body 1 orang.

b. Pemetaan kualifikasi berdasarkan job description dan KKNI untuk jabatan Kepala Bagian berada pada jenjang 6 setara dengan S1 atau D4 dan jenjang 7 setara dengan S2 atau Profesi. Untuk jabatan Operator Mould, Operator Milling Bahan Baku Body, Operator Milling Bahan Baku Glaze, Operator Painting, Operator Pressure Casting, Operator Casting, Operator Finishing, Operator Decal, Operator Pencelupan warna (glazing), dan Operator Roll Kiln dan Operator Packing berada pada jenjang 2 setara dengan SMA/SMK/MA dan jenjang 3 setara dengan D1.

c. Hasil capaian produksi setelah di terapkan perhitungan nilai FTE dan pengoptimalan karyawan berdasarkan KKNI maka didapatkan persentase nilai sebesar 98,11\% pada bulan Juli dan Agustus 2019. Hasil capaian produksi meningkat $1,17 \%$ dari hasil capaian produksi dibulan Januari-Juni 2019 yaitu hanya sebesar 96,94\%. Sehingga Produktivitas pada bulan Juli dan 
Agustus mengalami peningkatan sebesar 1754.31 pcs/orang dari jumlah rata-rata sebelumnya yaitu 1733,59 pada bulan Januari-Juni 2019. Maka di dapat persentase angka kenaikan produktivitas PT. Rosy Ceramindo selama 2 bulan sebesar 1,20\% dari bulan seebelumnya.

\subsection{Saran}

Adapun saran yang dapat diberikan penulis dari hasil penelitian yang telah dilakukan adalah sebagai berikut:

a. Pemetaan karyawan yang dibuat berdasarkan job description, KKNI, dan persyaratan jabatan yang ditetapkan perusahaan, dapat menjadi pertimbangan sebagai persyaratan jabatan yang baru agar dapat bersaing dalam persaingan global.

b. Pemetaan karyawan yang dibuat hanya berdasarkan KKNI. Sebaiknya untuk penelitian selanjutnya disesuaikan dengan Standar Kompetensi Kerja Nasional Indonesia (SKKNI).

c. Untuk penelitian selanjutnya sebaiknya dibandingkan dengan job specification.

\section{DAFTAR PUSTAKA}

Adawiyah, S. (2013). Analisis Beban Kerja Sumber Daya Manusia dalam Aktivitas Produksi Komoditi Sayuran Selada. Jurnal Manajemen dan Organisasi Vol IV, No. 2, , 129-143.

Ajitia N, P. (2017). Efektivitas Manpower Planning Dengan Menggunakan Metode Analisis Beban Kerja (Work Load Analysis) Berdasarkan Pendekatan Full Time Equivalent . Jurnal Administrasi Bisnis Vol. 42 No.1, 27-35.

Anisa, H. N. (2017). Analisis Beban Kerja Pegawai Dengan Metode Full Time Equivalent (Fte). Jurnal Teknik Industri, 1-8.

Benge, H. (2015). A 10-Year Analysis of "Revenues," Costs, Staffing, and Workload in an Academic Medical Center Clinical Chemistry Laboratory. CLIN.CHEM, 17801787.

Dhakiri, H. (2016, Mei 3). Penerapan Standar Kompetensi Kerja Nasional Indonesia Kategori Jasa Profesional, Ilmiah Dan Teknis Golongan Pokok Kegiatan Kantor Pusat Dan Konsultasi Manajemen Bidang Sistem Manufaktur. Retrieved from Keputusan Menteri Ketenagakerjaan Republik Indonesia No. 136 Tahun 2016: https://kemenperin.go.id

Dhakiri, H. (2016, Juni 24). Penetapan Standar Kompetensi Kerja Nasional Indonesia Kategori Industri Pengolahan Golongan Pokok Industri Barang Galian Bukan Logam Bidang Industri Keramik Tableware Dan Sanitary . Retrieved from Keputusan Menteri Ketenagakerjaan Republik Indonesia No. 190 Tahun 2016: https://kemenperin.go.id

Diniaty, \& Muliyadi. (2016). Analisis Beban Kerja Fisik Dan Mental Karyawan Pada Lantai Produksi Dipt Pesona Laut Kuning . Jurnal Sains, Teknologi dan Industri, Vol. 13, No. 2, 203 - 210 .

Fahmy, M. R. (2018). Analisis Beban Kerja Dengan Metode Full Time Equivalent Untuk Mengoptimalkan Kinerja Pada Teknisi Maintenance Rtg . Conference on Safety Engineering and Its Application, 502-506.

Hamali, Y. (2016). Pemahaman Manajemen Sumber Daya Manusia. Bandung: CAPS (Center For Academic Publishing Service).

Jessup, M. (2011). Current Staffing Profile Of Heart Failure Programs, Including Programs That Perfome Heart Transplant And Mechanical Circulatory Support Device Implantation. Journal of the American College of Cardiology Vol. 57, No. 20, 2116-2124.

Koesomowidjojo, S. (2017). Analisis Beban Kerja. Jakarta: Raih Asa Sukses.

Lauren B. Angelo. (2007). Impact of Community Pharmacy Automation on Workflow, Workload, and Patient Interaction. Journal of the American Pharmacists Association Vol. 45, No. 2, 138-144. 
Meikel Zekben S, H. P. (2016). Penentuan Beban Kerja Dan Kebutuhan Tenaga Kerja Dengan Menggunakan Metode Fte ( Full Time Equivalent) Pada Bagian Produksi Non Betalaktam . Jurnal Teknik Industri, 1-11.

Nurul, \& Prayoga. (2019). Analisis Kebutuhan Karyawan Dengan Menggunakan Metode Full Time Equivalent (Fte) Pada Departemen Produksi Pt. Borsya Cipta Communica . JURNAL TAMBORA VOL. 3 NO. 2 , 98-106.

Prayonne, A. (2017). Pengukuran Beban Kerja Pada Departemen PPIC Di PT. X . Jurnal Titra, Vol. 5 No.2, 45-55.

Putri, P. (2018). Penentuan Jumlah Karyawan Dengan Metode Full Time Equivalent . Seminar Nasional IENACO, 173-177.

Samuel, A. (2018 ). Analisis Beban Kerja Pada Cleaning Service Di Pt. Xyz Dengan Metode Full Time Equivalent . Jurnal Teknik Industri, Vol. 13, No. 1, 1-6.

Sari, D., \& Hardiansa. (2018). workload assessment on foundry sme to enhance productivity using full time equivalent. MATEC Web of Conferences, 1-5.

Sinungan, M. (2009). Produktivitas Apa Dan Bagaimana. Jakarta: PT. Bumi Aksara.

Sumartono, A. (2012, Januari 17). Kerangka Kualifikasi Nasional Indonesia . Retrieved from Peraturan Presiden Republik Indonesia No. 8 Tahun 2012: https://www.kopertis7.go.id

Tridoyo, S. (2017). Analisis Beban Kerja Dengan Metode Full Time Equivalent Untuk Mengoptimalkan Kinerja Karyawan Pada Pt Astra International Tbk-Honda Sales Operation Region Semarang . Jurnal Ilmiah Teknik Industri, 1-8.

Utary, A. (2018). Analisis Kebutuhan Pengembangan Sdm Bidang Bina Marga Dinas Pupr Provinsi Ntb . Jurnal Magister Manajemen Unram Vol. 7, No 2. , 36-49.

Widiawati. (2009). time and motion study untuk mengetahui waktu baku di produksi sambal PT. Heinz ABC. Jurnal Teknik Industri, 56-62.

Widya S, M. (2017). Analisis Beban Kerja Karyawan Bagian Produksi Dengan Menggunakan Metode Full Time Equivalent (FTE) Di UD Roti Alvine. ARIKA, 89-96.

Wignjosoebroto, S. (2017). Ergnomi Studi Gerak Dan Waktu, Teknik Analisis Untuk Peningkatan Produktivitas Kerja. Surabaya: Prima Printing.

Yasmin, A. (2018). Analisis Beban Kerja Pada Maintenance Bd-Check Dengan Metode Full Time Equivalent . Jurnal Ilmiah Teknik Industri Vol. 6 No. 1, 55-62. 
